\title{
Orobanche mayeri (Suess. \& Ronniger) Bertsch \& F. Bertsch - a species new to Poland
}

\author{
Renata Piwowarczyk* \\ Institute of Biology, Jan Kochanowski University in Kielce, Świętokrzyska 15, 25-406 Kielce, Poland
}

\section{Abstract}

Two new localities of Orobanche mayeri (Suess. \& Ronniger) Bertsch \& F. Bertsch, one of the rarest representatives of the family Orobanchaceae in Europe, are reported from southern Poland. The species was recorded in the Pieniny Mts (Central Western Carpathians) in July 2009. The hosts, abundance and habitat preferences at the new localities are described and a supplemented map of the distribution in Europe and Poland is given.

Keywords: Orobanchaceae, Orobanche mayeri, distribution, habitat, Pieniny Mts, Poland

\section{Introduction}

Orobanche mayeri (Suess. \& Ronniger) Bertsch \& F. Bertsch, Mayer's broomrape, is one of the rarest representatives of the family Orobanchaceae in Europe. It was known only from single localities in Germany, Slovakia and Romania prior to this report. It is red-listed as a threatened species in Baden-Württemberg [1] and Germany: (category R) [2], as a highly endangered of extinction [3], as well as in Slovakia (category LRr) [4]. It is considered to be threatened in central Europe (Verantwortlichkeit Mitteleuropas, VME) [5,6].

The species was discovered by the botanist and pharmacists Adolf Mayer (1871-1952) from Germany in Zeller Horn in the Swabian Alb in Baden-Württemberg in 1940 and incorrectly determined as O. elatior. It was later revised by Süssenguth and Ronniger [7] and identified as O. alsatica var. mayeri. The taxon, considered to be endemic, was known only from one locality in Europe. It was later recorded at over ten localities in the Slovakian Carpathians in the 1990s [4].

\section{General distribution}

Orobanche mayeri is a rare species associated mostly with the flora of the Western Carpathians, especially with the area of the Central Carpathians [4]. Its distribution is not fully known.

Orobanche mayeri was first reported from Germany [7]. It was treated as an endemic taxon but was later recorded at over ten localities in Slovakia in the Carpathians. It was mostly

\footnotetext{
*Email: renka76@wp.pl

This is an Open Access digital version of the article distributed under the terms of the Creative Commons Attribution 3.0 License (creativecommons.org/licenses/ by/3.0/), which permits redistribution, commercial and non-commercial, provided that the article is properly cited.
}

(c) The Author(s) 2011 Published by Polish Botanical Society recorded in the Nizkie Tatra Mts (district: Demänovská dolina, Liptovský Hrádok, Krakova hola, Malužiná, Čierny Váh) and was collected at one locality in the Choczańskie Góry Mts (Kvačianska valley) and at three localities in the Western Beskidy Mts in Orava [4].

Pujadas-Salvá and Gómez-Garciá [8] report one more locality from Romania, from the southern Carpathians, based on a herbarium specimen in Jena: Bucegi Plateau, $2000 \mathrm{~m}$, 14.07.1961, leg. K. Shäfer, JE (Fig. 1). The locality needs confirmation.

The location given by Kaiser [9] from Karlstadt (Kalbenstein) in Bavaria is incorrect and belongs to Orobanche alsatica [10] (Uhlich personal communication, 2010).

\section{Taxonomic notes}

Orobanche mayeri (Suess. \& Ronniger) Bertsch \& F. Bertsch [11]. Basionym: Orobanche alsatica Kirschleger var. mayeri Süssenguth \& Ronniger [7]. Syn.: Orobanche alsatica var. mayeri Süssenguth et Ronniger; O. alsatica subsp. mayeri (Suess. \& Ronniger) Kreutz [12].

The complex of morphologically similar species treated as $O$. alsatica agg., in which $O$. mayeri is included, requires special and critical taxonomic revision. The species is also morphologically similar to O. flava [4]. A list of characters differentiating the species within the $O$. alsatica agg. is given in a study by Pujadas-Salvá and Gómez-Garciá [8].

Although it was described by Süssenguth and Ronniger [7] as a variety of $O$. alsatica and reported as a subspecies in Kreutz [12], Rothmaler [13] and Pusch and Günther [10]. O. mayeri seemed to differ sufficiently by distinct morphological and ecological characters that it could be raised to the rank of species. This was done by Bertsch and Bertsch [11] and the rank was later accepted by Hepp [14], Nieschalk and Nieschalk [15], Zázvorka [4], Senghas and Seybold [16] as well as PujadasSalvá and Gómez-Garciá [8].

In the original description of O. alsatica subsp. mayeri, Süssenguth and Ronniger [7] report bright yellow taxa. However, 
only a few plants were yellow at the locus calssicus while the colour of most specimens ranged from light to dark brown [12]. Pink-red or reddish plants are also reported by [4]. Many species of the genus Orobanche, including those within the $O$. alsatica sensu lato group, are often yellow; however, they almost never constitute the majority of a population. Such pigmentation is not typical and is a result of the insolation rate or incomplete plant pigmentation. Yellow and albinotic varieties can usually occur in more shaded sites.

\section{Biology and habitat conditions}

The locality in Zeller Horn, is situated in a NW-facing mountain meadow $(840-900 \mathrm{~m})$. Orobanche mayeri grows on calcareous, loamy soil, with solitary beech trees. The area was declared a protected nature reserve in 1950 and is one of the most important plant habitats in the Swabian Alb [12]. It grows in Germany in the ass. Bupleuro longifolii-Laserpitietum latifolii (Geranion sanguinei, Origanetalia) [13] (Uhlich personal communication, 2009).

O. mayeri grows at altitudes from 650 to $1000 \mathrm{~m}$, maximum $1500 \mathrm{~m}$, at the localities in Slovakia. It usually occurs on S-facing habitats, on grassy slopes, overgrowing rocks, in relict pine groves and thinned spruce forests as well as in relict montane xerothermic grasslands on dolomites and limestone. In Slovakia the plant grows in Erico-Pinion (= Pulsatillo slavicae-Pinion) and Laserpitio-Calamagrostietum variae (Seslerietalia). It is often accompanied by $O$. reticulata [4].

O. mayeri flowers from the end of June until the end of July (August) [4,12]. Laserpitium latifolium is its exclusive host $[10,12]$. Zázvorka [4] additionally reports another host plant, Pimpinella major subsp. rhodochlamys, from the locality in Ohnište in the Nizkie Tatra Mts.

\section{Methods}

Field studies were carried out in July in 2009. The localities are situated in the Western Carpathian province, Central Western Carpathians subprovince, Obniżenie Orawsko-Podhalańskie depression macroregion, Pieniny mesoregion [17]. The distribution of its localities was mapped using the ATPOL grid based on cartogram units $10 \times 10 \mathrm{~km}$ [18].

The nomenclature of the vascular plant species listed in the phytosociological table follows Mirek et al. [19] and the nomenclature of syntaxa is used after Matuszkiewicz [20]. Phytosociological relevés were conducted using the Braun-Blanquet method [21].

\section{Results}

\section{New localities}

Two localities of $O$. mayeri, separated by $1.5 \mathrm{~km}$ in a straight line, were recorded in southern Poland in the Central Pieniny Mts, ATPOL EG33 (Fig. 1, Fig. 2).

BIAŁE SKAŁY. The ecotone zone of an overgrowing rock grassland and a thinned oak-hornbeam forest on the S-facing slope of the Białe Skały rocks, near the blue tourist trail, $49^{\circ} 25^{\prime} 31.1^{\prime \prime} \mathrm{N} / 20^{\circ} 25^{\prime} 19^{\prime \prime} \mathrm{E}$, alt. $725 \mathrm{~m}$. Species of the QuercoFagetea class dominate in the community with a very small participation of the Seslerietea variae, Festuco-Brometea and

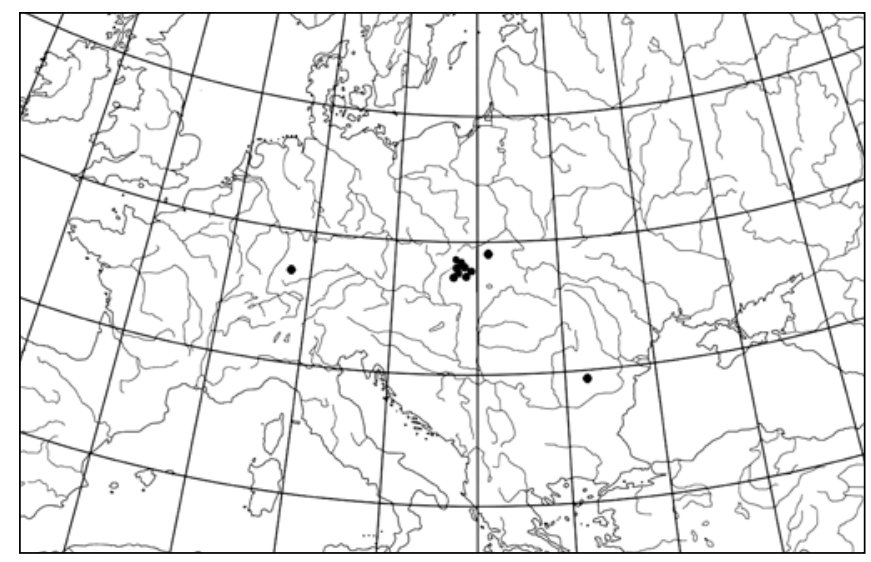

Fig. 1 General distribution map of Orobanche mayeri.

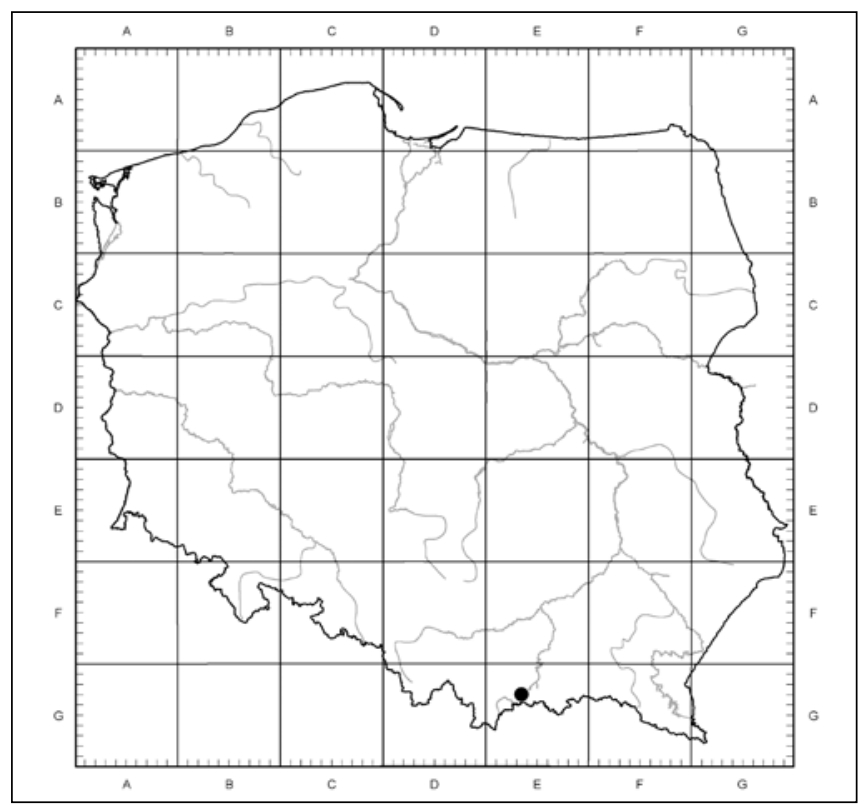

Fig. 2 Distribution of Orobanche mayeri in Poland (in the ATPOL grid, $10 \times 10 \mathrm{~km}$ ). Black circles - new localities.

Trifolio-Geranietea sanguinei classes. Only five specimens were recorded.

TRZY KORONY. S-, SE- and SW-facing rock ledges and cliffs below the Okrąglica summit, $49^{\circ} 24^{\prime} 49.4^{\prime \prime} \mathrm{N} / 20^{\circ} 24^{\prime} 51^{\prime \prime} \mathrm{E}$, alt. $915-967 \mathrm{~m}$. The species is scattered in a xerothermic grassland of the Festuco-Brometea class in the ecotone zone with rock grasslands of the Dendranthemo-Seslerietum ass. (Seslerietea variae class); with a high occurrence of species of the Trifolio-Geranietea sanguinei and Querco-Fagetea classes. A total of ca. 30 specimens were recorded. The majority of the specimens were observed in an open, S-facing xerothermic grassland (Fig. 3).

A detailed list of species recorded at the localities is given in Tab. 1.

\section{Conclusions}

The calcareous substrate, the exceptional geomorphological and microclimatic differentiation, the absence of glaciation, the vicinity of the Tatra Mts and calcareous Slovakian 


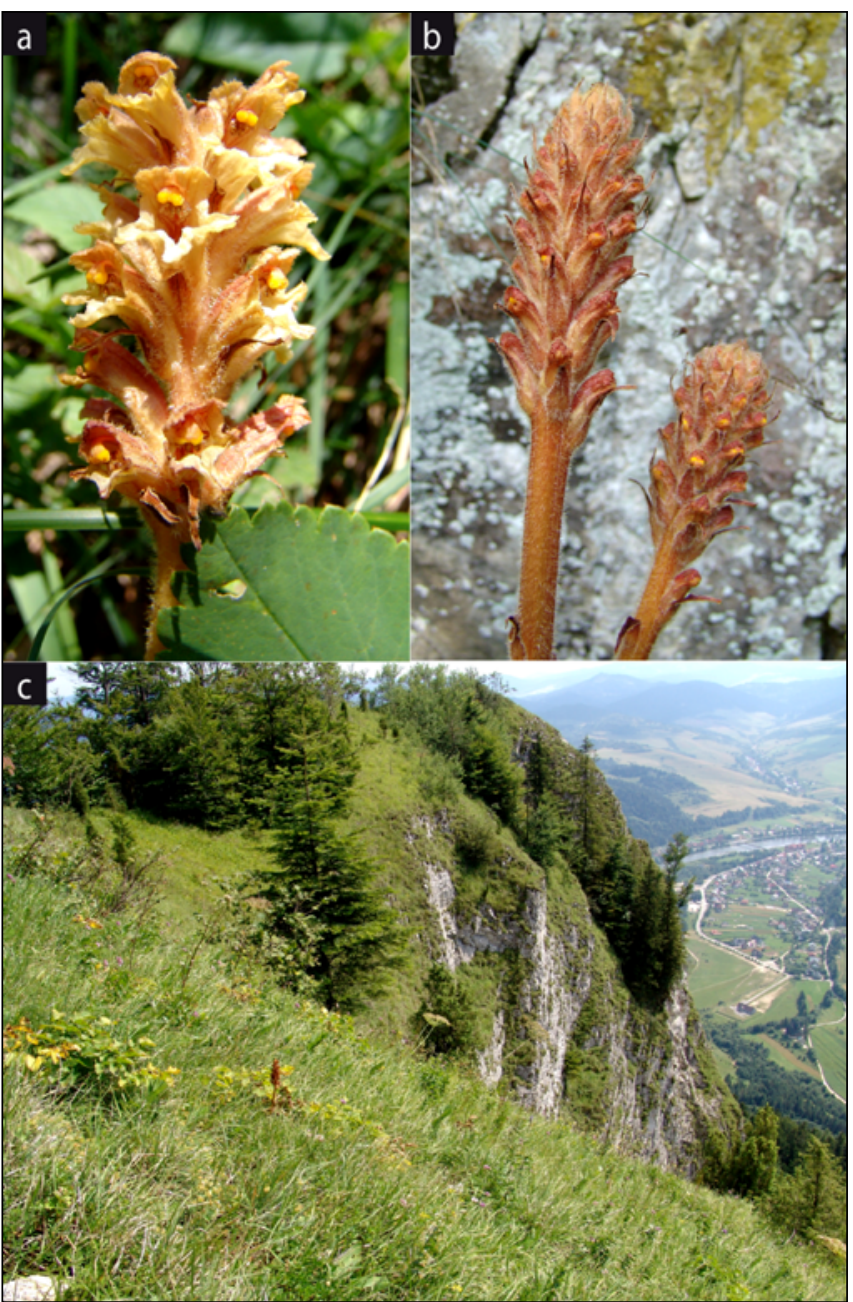

Fig. 3 Orobanche mayeri. a,b Inflorescences. c Xerothermic grassland with species on Okrąglica. Photo by R. Piwowarczyk, 2009.07.30. ranges and, consequently, migration opportunities between the ranges, and the low altitude of the range influence a high differentiation of the vegetation in the Pieniny Mts. Relicts, that is plants that have survived at their localities from the earliest geological periods and live in isolated populations at considerable distances from their range limits, also occur in the area.

Orobanche mayeri grows in the Pieniny Mts in rock grassland communities, especially in the ecotone zone of two classes that represent them: xerothermic grasslands of Festuco-Brometea class and montane grasslands Seslerietea variae developing on calcareous substrate. In the former, Dendranthemo-Seslerietum variae, a rock montane grassland and an endemic association in the Pieniny Mts, is particularly interesting. Scrub and forest species of the Trifolio-Geranietea sanguinei and QuercoFagetea classes often occur in the communities occupied by $O$. mayeri. This is associated with progressing secondary succession and the mosaic pattern of phytocoenoses (Tab. 1).

Communities occupied by O. mayeri in Germany and Slovakia are similar to Polish localities. They are rare communities of the Geranion sanguinei, Seslerietalia or Erico-Pinion $[4,16]$. It should be added that the occurrence of range limit and impoverished forms of communities of the Erico-Pinetea class in the Polish Pieniny Mts has been the subject of several controversies and requires further investigation [20].

The montane occurrence is observed within the species' range. O. mayeri most frequently occurs at ca. $725-967 \mathrm{~m}$ in Poland, ca. 840-900 in Germany [12], 650-1000, rarely at 1500 in Slovakia [4] and $2000 \mathrm{~m}$ in Romania (after [8]).

The species grows to a height of 35 to $45(55) \mathrm{cm}$ at its localities in Slovakia [4] and up to $60 \mathrm{~cm}$ in Germany [12]. It was between 22 and $60 \mathrm{~cm}$ tall at the Polish localities.

As a rarely occurring species with a small distribution range, O. mayeri is highly threatened in Europe. Additionally, populations at its localities are not numerous. Only two specimens were recorded in Zeller Horn in 2008 [22], nine in 2009 (Uhlich personal communication). Its populations range from

Tab. 1 Plant communities with Orobanche mayeri.

\begin{tabular}{|c|c|c|c|c|}
\hline Number of relevé & 1 & 2 & 3 & 4 \\
\hline Location & Białe Skały & Okrąglica 1 & Okrąglica 2 & Okrąglica 3 \\
\hline Date & 29.07.2009 & 30.07.2009 & 30.07.2009 & 30.07 .2009 \\
\hline Area of relevé $\left(\mathrm{m}^{2}\right)$ & 25 & 25 & 40 & 25 \\
\hline Exposure & $\mathrm{S}$ & SE & SE & $S$ \\
\hline Latitude $(\mathrm{N})$ & $49^{\circ} 25^{\prime} 31.1 ”$ & $49^{\circ} 24^{\prime} 50.4^{\prime \prime}$ & $49^{\circ} 24^{\prime} 50.8^{\prime \prime}$ & $49^{\circ} 24^{\prime} 49.4^{\prime \prime}$ \\
\hline Longitude (E) & $20^{\circ} 25^{\prime} 19^{\prime \prime}$ & $20^{\circ} 24^{\prime} 49.8^{\prime \prime}$ & $20^{\circ} 24^{\prime} 50.9^{\prime \prime}$ & $20^{\circ} 24^{\prime} 51^{\prime \prime}$ \\
\hline Altitude (m) & 725 & 967 & 915 & 921 \\
\hline Density of tree layer A (\%) & 75 & 30 & 30 & 0 \\
\hline Density of shrub layer B (\%) & 20 & 15 & 10 & 15 \\
\hline Density of herb layer C (\%) & 60 & 95 & 75 & 100 \\
\hline Number of species & 27 & 45 & 46 & 34 \\
\hline Orobanche mayeri & + & + & + & + \\
\hline \multicolumn{5}{|l|}{ Ch. Dendranthemo-Seslerietum variae } \\
\hline Sesleria varia & + & 3 & 1 & 4 \\
\hline Centaurea triumfetti & . & . & + & + \\
\hline Dendranthema zawadzkii & . & . & + & + \\
\hline Erysimum wittmannii & . & . & $\mathrm{r}$ & + \\
\hline Helianthemum alpestre subsp. rupifragum & . & . & + & + \\
\hline
\end{tabular}


Tab. 1 (continued)

Number of relevé 1

\section{Ch. Seslerietea variae}

Carduus glaucus

Jovibarba hirta subsp. glabrescens

Scabiosa lucida

Ch. Festuco-Brometea

Allium montanum

Festuca pallens

Euphorbia cyparissias

Teucrium montanum

Ch. Trifolio-Geranietea sanguinei

Campanula rapunculoides

Libanotis pyrenaica

Bupleurum falcatum

Coronilla varia

Clinopodium vulgare

Polygonatum odoratum

Ch. Querco-Fagetea

Fagus sylvatica A

Corylus avellana $\mathrm{B}$

Melica nutans

Acer pseudoplatanus C

Epipactis helleborine

Lathyrus vernus

Lonicera xylosteum B

Lonicera xylosteum C

Others

Laserpitium latifolium

Digitalis grandiflora

Vincetoxicum hirundinaria

Calamagrostis varia

Picea abies A

Galium mollugo s.l.

Cotoneaster integerrimus $\mathrm{C}$

Bupleurum longifolium

Thymus pulegioides

Fragaria vesca

Rosa dumalis C

Rubus idaeus

Aconitum variegatum

Cotoneaster integerrimus B

Hypericum perforatum

Lathyrus pratensis

Mycelis muralis

\begin{tabular}{|c|c|c|c|}
\hline+ & + & + & + \\
\hline . & + & . & + \\
\hline . & + & + & . \\
\hline+ & + & + & 2 \\
\hline . & + & + & 1 \\
\hline . & + & + & + \\
\hline+ & . & . & + \\
\hline+ & + & + & + \\
\hline+ & + & + & + \\
\hline . & . & + & + \\
\hline . & . & + & + \\
\hline+ & . & + & . \\
\hline . & + & + & . \\
\hline 3 & 2 & 2 & . \\
\hline+ & + & . & + \\
\hline 3 & . & + & . \\
\hline+ & . & + & . \\
\hline+ & + & . & . \\
\hline . & + & + & . \\
\hline+ & . & + & . \\
\hline+ & . & + & . \\
\hline 1 & 1 & 1 & 1 \\
\hline+ & + & + & + \\
\hline+ & + & + & 1 \\
\hline . & 4 & 1 & + \\
\hline 2 & + & 2 & . \\
\hline . & + & + & + \\
\hline . & + & + & + \\
\hline . & + & + & + \\
\hline . & + & + & + \\
\hline+ & + & + & . \\
\hline+ & + & . & + \\
\hline . & + & 2 & . \\
\hline . & + & + & . \\
\hline . & + & . & + \\
\hline . & + & . & + \\
\hline . & + & + & . \\
\hline+ & . & + & . \\
\hline
\end{tabular}

SPORADIC: Ch. Dendranthemo-Seslerietum variae: Astragalus australis 2(r); Bellidiastrum michelii 3. Ch. Festuco-Brometea: Dianthus carthusianorum 3; Veronica spicata 4. Ch. Querco-Fagetea: Acer pseudoplatanus A 1(1); Actaea spicata 2; Corylus avellana C 1; Euphorbia amygdaloides 1; Galium odoratum 2; G. schultesii 2; Lilium martagon 2; Viola reichenbachiana 1. Others: Abies alba A 3(1); B 1(1); C 2; Alyssum saxatile 4(r); Briza media 3; Cirsium sp. 2; Cornus sanguinea B 1; C 1; Epipactis atrorubens 4; Euphrasia salisburgensis 4; Fagus sylvatica B 1; C 1; Gypsophila repens 3(r); 4(r); Heracleum sphondyllium 3; Juniperus communis B 4(1); Picea abies B 3; C 1; Medicago falcata 3; Orobanche caryophyllacea 2; Polygonatum verticillatum 1; Salix silesiaca A 2(1); Senecio nemorensis 2; Tanacetum corymbosum subsp. clusii 2; Taraxacum sp. 2; Tussilago farfara 2; Urtica dioica 3.

five to 30 specimens in Poland. The most numerous populations and the greatest density of localities have been observed in Slovakia.

Relict habitats occupied by O. mayeri at the European localities and the disjunctive and limited distribution range also indicate its relict character. Investigations planned by the author should provide further data on the distribution, taxonomy and ecology of the taxon.

The new localities of the species are within the protected area of the Pieniny National Park. Progressing secondary 
succession and the proximity of tourist trails pose a threat to the species.

\section{Acknowledgements}

The author thanks Prof. Adam Zając for his helpful comments on the manuscript, Holger Uhlich for providing the information on the current occurrence of the species in Germany and Marek Podsiedlik for his help during field studies. The author is also grateful to Prof. Jerzy Zieliński for the determination of species of the genera Rosa and Salix and to Ewa Posz for the determination of Euphrasia.

This work was supported by the Polish State Committee for Scientific Research (KBN grant No. NN303357733 in 2009 and NN303551939 in the years 2010-2011).

\section{References}

1. Breunig T, Demuth S. Rote Liste der Farn- und Samenpflanzen Baden-Württemberg. 3rd ed. Karlsruhe: Landesanstalt für Umweltschutz Baden-Württemberg; 1999. (Naturschutz-Praxis. Artenschutz; vol 2).

2. Korneck D, Schnittler M, Vollmer I. Rote Liste der Farnund Blütenpflanzen (Pteridophyta et Spermatophyta) Deutschlands. In: Schriftenreihe für Vegetationskunde. 1996. p. 21-187. (vol 28).

3. Ludwig G, May R, Otto C. Verantwortlichkeit Deutschlands für die weltweite Erhaltung der Farn- und Blütenpflanzen - vorläufige Liste. BfN-Skripten. 2007;220:1-102.

4. Zázvorka J. Orobanchaceae Vent. Zárazovité. In: Goliašová K, editor. Flóra Slovenska. Bratislava: Veda; 1997. p. 460529. (vol V/2).

5. Schnittler M, Günther KF. Central European vascular plants requiring priority conservation measures - an analysis from national red lists and distribution maps. Biodiversity Conserv. 1999;8(7):891-925. doi:10.1023/A:1008828704456.

6. Welk E. Arealkundliche Analyse und Bewertung der Schutzrelevanz seltener und gefährdeter Gefässpflanzen Deutschlands. Münster: Bundesamt für Naturschutz; 2002. (Schriftenreihe für Vegetationskunde; vol 37).

7. Süssenguth K, Ronniger K. Über Orobanche alsatica Kirschl. var. Mayeri Sss. et Ronniger. Eine neue Orobanche aus der Schwäbischen Alb. Beitr Naturk Forsch Oberrheingebiet. 1942;7:123-127.

8. Pujadas Salvá AJ, Gómez Garciá D. Orobanche montserratii A. Pujadas \& D. Gómez (Orobanchaceae) new species from the Huesean Pyrenees. Anal Jard Bot Madr. 2000;57(2). doi:10.3989/ajbm.1999.v57.i2.202.

9. Kaiser E. Die Steppenheiden des mainfränkischen Wellenkalkes zwischen Würzburg und dem Spessart. Ber Bayr Bot Ges. 1950;28:125-180.

10. Pusch J, Günther KF. Orobanchaceae (Sommerwurzgewächse). In: Hegi G, editor. Illustrierte Flora von Mitteleuropa. Jena: Weissdorn-Verlag; 2009. p. 1-99. (vol 6).

11. Bertsch K, Bertsch F. Flora von Württemberg und Hohenzollern. Zum Gebrauch auf Wanderungen, in Schulen und beim Selbstunterricht. 2nd ed. Stuttgart: Wissenschaftliche Verlagsgesellschaft; 1948.

12. Kreutz C. Orobanche: die Sommerwurzarten Europas. Mittel- und Nordeuropa. Maastricht: Natuurhistorisch Genootschap in Limburg; 1995. (vol 1).

13. Jäger EJ, Werner K, editors. Rothmaler - Exkursionsflora von Deutschland. 9th ed. Berlin: Spektrum Akademischer Verlag; 2002. (vol 4).

14. Hepp E. Neue Beobachtungen über die Phanerogamenund Gefasskryptogamenflora von Bayern, 8/2. Ber Bayr Bot Ges. 1956;31:24-53.

15. Nieschalk A, Nieschalk C. Mitteilungen zur Verbreitung von Orobanche bartlingii Grisebach [= Orobanche libanotidis Ruprecht, O. alsatica Kirschleger var. libanotidis (Ruprecht) Beck] in Bayern. Ber Bayer Bot Ges. 1974;45:71-74.

16. Senghas K, Seibold S, editors. Schmeil-Fitschen: Flora von Deutschland und angrenzender Länder. 93rd ed. Wiebelsheim: Quelle \& Meyer; 2003.

17. Kondracki J. Geografia regionalna Polski. 2nd ed. Warszawa: Polish Scientific Publishers PWN; 2001.

18. Zając A. Założenia metodyczne "Atlasu rozmieszczenia roślin naczyniowych w Polsce". Wiad Bot. 1978;22(3):145-155.

19. Mirek Z, Piękoś-Mirkowa H, Zając A, Zając M. Flowering plants and pteridophytes of Poland - a checklist. Kraków: W. Szafer Institute of Botany, Polish Academy of Sciences; 2002. (Biodiversity of Poland; vol 1).

20. Matuszkiewicz W. Przewodnik do oznaczania zbiorowisk roślinnych Polski. 3rd ed. Warszawa: Polish Scientific Publishers PWN; 2007.

21. Braun-Blanquet J. Pflanzensoziologie: Grundzüge der Vegetationskunde. 3rd ed. Wien: Springer; 1964.

22. Höniges A. Ökologische und Physiologische Studien an Orobanche Arten in natürlichen Ökosystemen $[\mathrm{PhD}$ thesis]. Tübingen: Eberhard Karls University; 2009. 